\title{
Aclidinium bromide/formoterol fixed-dose combination therapy for COPD: the evidence to date
}

This article was published in the following Dove Press journal:

Drug Design, Development and Therapy

7 April 2015

Number of times this article has been viewed

\author{
Subhabrata Moitra' \\ Arvind B Bhome ${ }^{2}$ \\ Bill B Brashier ${ }^{\prime}$ \\ 'Chest Research Foundation, Pune, \\ Maharashtra, India; ${ }^{2}$ Indian Coalition \\ of Obstructive Lung Diseases \\ (ICOLD) Network, Pune, Maharashtra, \\ India
}

\begin{abstract}
The quest for the right combination of bronchodilators with different mechanisms of action such as long-acting muscarinic antagonists and long-acting $\beta$-agonists in the management of stable moderate-to-severe chronic obstructive pulmonary disease (COPD) is a topic of intense research activity currently, given the rising morbidity and mortality due to this disease. The fixed-dose combination of aclidinium bromide and formoterol fumarate in a single inhaler seems to offer superior advantages over either drugs given alone or as separate inhalers concurrently. Since the fixed-dose combination needs to be given twice daily, it is likely to achieve control of symptoms most crucial to the quality of life in COPD, namely, the morning hours. This is reflected in significant trough $\mathrm{FEV}_{1}$ (forced expiratory volume in 1 second) improvements after the dose. This paper reviews the various studies related to this combination put in the perspective of its safety and efficacy and potential benefits over other therapeutic options. However, there is a dearth of data on the long-term safety and efficacy in terms of improvement in lung function. This combination could emerge as an excellent option in the management of stable COPD if data on exacerbation rates and patient-reported outcomes become available from longer-term studies. Moreover, we need some more studies to define the ideal phenotype of COPD best suited for the use of this combination.
\end{abstract}

Keywords: aclidinium, formoterol, COPD, lung function, bronchodilators, combination therapy

\section{Introduction}

Chronic obstructive pulmonary disease (COPD) is a recalcitrant inflammatory disease of the lungs with irreversible and progressive airflow limitation and parenchymal destruction with significant systemic inflammatory components. It is the third most severe disease in terms of mortality and morbidity globally, and the World Health Organization (WHO) predicts that it would step up to the second leading cause of mortality by $2030 .^{1-6}$ The disease is manifested by dynamic hyperinflation, and the inflammation in COPD is steroid-nonresponsive. The inhaled corticosteroids (ICS) are the mainstay of treatment across all categories of asthma. However, in COPD, the therapeutic use of ICS is perhaps limited to reducing the rate of frequent exacerbations. The role of steroids in controlling the inflammation in COPD seems to be lacking the same class of evidence as compared to their role in asthma inflammation. Of note, ICS has no effect on dynamic hyperinflation in COPD as compared to the bronchodilators. Therefore, the only treatment that has shown significant merit in COPD management is the bronchodilators. ${ }^{7}$ Bronchodilators act by either stimulating $\beta_{2}$ agonist receptors or blocking muscarinic receptors. The long-acting bronchodilators are naturally the preferred drugs due to reduced frequency of dosing, which induces
Correspondence: Bill B Brashier

Chest Research Foundation,

Kalyani Nagar, Pune 4II 014 ,

Maharashtra, India

Tel +9l 202703536 I

Fax +9| $202703537 \mid$

Email brashierbill@hotmail.com
Drug Design, Development and Therapy 2015:9 1989-1999

1989

Dovepress

http://dx.doi.org/10.2147/DDDT.S53150 (c) (i) (5) 2015 Moitra et al. This work is published by Dove Medical Press Limited, and licensed under Creative Commons Attribution - Non Commercial (unported, v3.0) License. The full terms of the License are available at http://creativecommons.org/licenses/by-nc/3.0/. Non-commercial uses of the work are permitted without any further

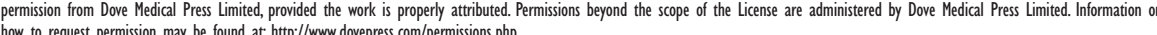
how to request permission may be found at: http://www.dovepress.com/permissions.php 
better compliance, reducing the symptoms for prolonged duration. The Global Initiative for Chronic Obstructive Lung Diseases $(\mathrm{GOLD})^{8}$ guidelines recommend combining the two types of long-acting bronchodilators with differing mechanisms of action if monotherapy is ineffective in controlling the disease. Several combination formulation compounds of long-acting muscarinic antagonists (LAMAs) and long-acting $\beta_{2}$ agonists (LABAs) have been clinically tested or are in the process of formulation, such as glycopyrrolate-formoterol, glycopyrronium-indacaterol, tiotropium-olodaterol, umeclidinium-vilanterol, and aclidinium-formoterol, in the management of obstructive airway disease. The pharmaceutical industries are investing in developing several once- or twice-daily LABA/LAMA combinations to improve COPD treatment in future either as free combinations in different devices or as a fixed-dose combination (FDC) in a single inhaler. ${ }^{9,10}$ It is hoped that FDCs could offer advantages of better compliance, adherence, and cost-efficacy in addition to synergistic action of the components in free combinations in separate devices. Table 1 presents recent evidences of the efficacy of these newer LAMAs and LABAs on the onset of action and improvement of trough forced expiratory volume in 1 second $\left(\mathrm{FEV}_{1}\right)$ among COPD patients. Table 2 presents results of some LABA and LAMA combinations as free combinations and FDCs.

Formoterol (LABA) and aclidinium bromide (LAMA) have shown significant individual efficacy in COPD management, and combination of these two drugs raises the promise of prospective therapeutic application in the management of COPD, although clinical evidences are still emerging. In this paper, we have taken an approach to revisit the evidences critically how the combination of these drugs could be useful in clinical practice.

\section{Formoterol fumarate - an effective LABA with unique advantages}

Formoterol is being used as a preferred bronchodilator in obstructive airway diseases over a long time. It has a stronger affinity to the receptors in contrast to other LABAs such as salmeterol. In a comparative study between salmeterol and formoterol, it was found that formoterol protected against methacholine-induced bronchial hyperresponsiveness in a dose-response manner and that effect was higher than that of salmeterol, which also suggested that salmeterol has properties of a partial agonist of $\beta_{2}$ receptors. ${ }^{11}$ Aalbers et al ${ }^{12}$ conducted a randomized, controlled study and demonstrated that COPD patients who received 9 and $18 \mu \mathrm{g}$ formoterol twice a day had reduced symptoms and increased number of symptom-free days; they also found that formoterol at a dose of $4.5 \mu \mathrm{g}$ or higher could significantly improve lung function in COPD patients. Gross et $\mathrm{al}^{13}$ also reported that formoterol fumarate delivered through nebulizers had improved lung function and Saint George's Respiratory Questionnaire (SGRQ) score, and compared to any short-acting $\beta_{2}$ agonist or short-acting muscarinic antagonist, formoterol imparts its action within 5 minutes of administration via any metered

Table I Comparison of various drugs in development of combination therapy with respect to frequency of dosage, rapidity of action, and quantum of improvement in trough FEV,

\begin{tabular}{|c|c|c|c|c|}
\hline Therapies & Manufacturer & Dosage & Time to onset & $\begin{array}{l}\text { Trough FEV } \\
\text { (difference from placebo) }\end{array}$ \\
\hline \multicolumn{5}{|l|}{ LABA } \\
\hline \multirow[t]{2}{*}{ Formoterol ${ }^{14}$} & Merck $^{\mathrm{a}}$ & Twice daily & $5 \mathrm{~min}$ & $50-90 \mathrm{~mL}$ \\
\hline & & $4.5 \mu \mathrm{g}(\mathrm{MDI})$ and $12 \mu \mathrm{g}(\mathrm{DPI})$ & & \\
\hline Indacaterol ${ }^{48}$ & Novartis & Once daily I50 and $300 \mu \mathrm{g}$ (EU) (DPI) & $5 \mathrm{~min}$ & $130-180 \mathrm{~mL}(P<0.00 \mid)$ \\
\hline Indacaterol ${ }^{48}$ & Novartis & Once daily $75 \mu \mathrm{g}$ (US) (DPI) & $5 \mathrm{~min}$ & $\geq 120 \mathrm{~mL}(P<0.00 \mathrm{I})$ \\
\hline Olodaterol $^{49}$ & Boehringer Ingelheim & Once daily 5 and $10 \mu \mathrm{g}\left(\right.$ Respimat $\left.^{\circledR}\right)$ & Not available & $6 \mathrm{I}-132 \mathrm{~mL}(P<0.0 \mathrm{I})$ \\
\hline Vilanterol $^{50}$ & GSK & Once daily 25 and $50 \mu \mathrm{g}$ (DPI) & Median 6 min & I37-165 mL $(P<0.001)$ \\
\hline \multicolumn{5}{|l|}{ LAMA } \\
\hline Aclidinium $^{18,51}$ & Almirall/Forest Laboratories & Twice daily $200-400 \mu g$ (DPI) & $10-30 \mathrm{~min}$ & $86-124 \mathrm{~mL}(P<0.000 \mathrm{I})$ \\
\hline Glycopyrronium $^{52,53}$ & Novartis & Once daily $50 \mu \mathrm{g}(\mathrm{DPI})$ & $5 \mathrm{~min}$ & $91-108 \mathrm{~mL}(P<0.00 \mathrm{I})$ \\
\hline Glycopyrrolate 52 & Pearl Therapeutics & Twice daily $36 \mu \mathrm{g}$ (MDI) & $5 \mathrm{~min}$ & $\begin{array}{l}\text { Statistically superior to } \\
\text { placebo } \\
(P<0.000 \text { I })\end{array}$ \\
\hline GSK233705 54 & GSK & Twice daily $200 \mu \mathrm{g}$ & Not available & $130 \mathrm{~mL}(P<0.00 \mid)$ \\
\hline Tiotropium ${ }^{55}$ & Boehringer Ingelheim & Once daily $18 \mu \mathrm{g}(\mathrm{DPI})$ and $5 \mu \mathrm{g}(\mathrm{SMI})$ & $15 \mathrm{~min}$ & $120-150 \mathrm{~mL}(P<0.001)$ \\
\hline
\end{tabular}

Notes: ${ }^{\circ}$ Other companies are developing formoterol as part of a fixed-dose combination. Adapted from Tashkin DP, Ferguson GT. Combination bronchodilator therapy in the management of chronic obstructive pulmonary disease. Respir Res. 2013;14:49.56

Abbreviations: $\mathrm{FEV}_{1}$, forced expiratory volume in I second; MDI, metered dose inhaler; DPI, dry powder inhaler; SMI, Soft Mist ${ }^{\mathrm{TM}}$ inhaler; LABA, long-acting $\beta_{2}$ agonist; LAMA, long-acting muscarinic antagonist; EU, European Union. 
Table 2 Currently available LABA and LAMA combinations

\begin{tabular}{|c|c|c|}
\hline Combination & Reference & Reported results \\
\hline \multicolumn{3}{|l|}{ Free combinations } \\
\hline $\begin{array}{l}\text { GSK233705: } 20 \text { or } 50 \mu \mathrm{g} \\
\text { BID; salmeterol: } 50 \mu \mathrm{g} \text { BID }\end{array}$ & Beier et $\mathrm{al}^{57}$ & $\begin{array}{l}\text { Larger mean increases from baseline trough FEV, vs placebo } \\
\text { with } 20 \mu \mathrm{g} \text { GSK } 233705 \text { + salmeterol }(203 \mathrm{~mL}) \text { and } 50 \mu \mathrm{g}\end{array}$ \\
\hline & & $\begin{array}{l}\text { GSK233705 + salmeterol }(215 \mathrm{~mL}) \text { vs monotherapy with } \\
\text { tiotropium (I0I mL) or salmeterol (II8 mL). }\end{array}$ \\
\hline $\begin{array}{l}\text { Tiotropium: I8 } \mu \mathrm{g} \text { QD; } \\
\text { arformoterol: I5 } \mu \mathrm{g} \text { BID }\end{array}$ & Tashkin et $\mathrm{al}^{58}$ & $\begin{array}{l}\text { Greater improvement in } \mathrm{FEV}_{1} \mathrm{AUC}_{0-24} \text { from baseline } \\
\text { with combination }(0.22 \mathrm{~L}) \text { vs monotherapy with either } \\
\text { arformoterol }(0.10 \mathrm{~L}) \text { or tiotropium }(0.08 \mathrm{~L}) ; P<0.00 \mathrm{I} \text {. }\end{array}$ \\
\hline $\begin{array}{l}\text { Tiotropium: } 18 \mu \mathrm{g} \text { QD; } \\
\text { formoterol: } 20 \mu \mathrm{g} \text { BID }\end{array}$ & Hanania et al $^{59}$ & $\begin{array}{l}\mathrm{FEV}_{1} \mathrm{AUC}_{0-3} \text { greater with combination }(\mathrm{I} .57 \mathrm{~L}) \mathrm{vs} \\
\text { tiotropium alone }(\mathrm{I} .38 \mathrm{~L}) ; \mathrm{P}<0.000 \mathrm{I} \text {. }\end{array}$ \\
\hline $\begin{array}{l}\text { Tiotropium: } 18 \mu \mathrm{g} \text { QD; } \\
\text { formoterol: } 12 \mu \mathrm{g} \text { BID }\end{array}$ & Tashkin et $\mathrm{al}^{60}$ & $\begin{array}{l}\text { Reduced use of rescue medication vs tiotropium alone; } P<0.05 \text {. } \\
\text { Greater improvement in } \mathrm{FEV}, \mathrm{AUC}_{0-4} \text { from baseline with } \\
\text { combination }(0.34 \mathrm{~L}) \text { vs tiotropium alone }(0.17 \mathrm{~L}) ; P<0.00 \mathrm{I} \text {. }\end{array}$ \\
\hline & & $\begin{array}{l}\text { Dyspnea significantly improved with combination at week } 8 \\
\text { (I.86) vs tiotropium alone }(\mathrm{I} .0 \mathrm{I}) ; P=0.0 \mathrm{I} 3 \text {. }\end{array}$ \\
\hline & & Reduced use of rescue medication vs tiotropium alone; $P<0.04$. \\
\hline $\begin{array}{l}\text { Tiotropium: } 18 \mu \mathrm{g} \text { QD; } \\
\text { formoterol: } 10 \mu \mathrm{g} \text { BID }\end{array}$ & Vogelmeier et $\mathrm{al}^{61}$ & $\begin{array}{l}\text { Improvement in FEV, } 2 \text { h postdose after } 24 \text { weeks with } \\
\text { combination vs formoterol alone }(P=0.044) \text {. }\end{array}$ \\
\hline $\begin{array}{l}\text { Tiotropium: } 18 \mu \mathrm{g} \text { QD; } \\
\text { salmeterol: } 50 \mu \mathrm{g} \text { BID }\end{array}$ & van Noord et al ${ }^{62}$ & $\begin{array}{l}\text { Improved average } \mathrm{FEV}_{1}(0-24 \mathrm{~h}) \text { with combination }(0.142 \mathrm{~L}) \text { vs } \\
\text { monotherapy with either tiotropium }(0.07 \mathrm{~L}) \text { or salmeterol } \\
(0.045 \mathrm{~L}) ; P<0.000 \mathrm{I} \text {. Combination associated with clinically } \\
\text { relevant improvements in TDI focal score }(P<0.00 \mathrm{I}) \text {. }\end{array}$ \\
\hline \multicolumn{3}{|l|}{ Fixed-dose combinations } \\
\hline $\begin{array}{l}\text { Glycopyrrolate: } 36 \text { and } 72 \mu \mathrm{g} \text { BID; } \\
\text { formoterol: } 9.6 \mu \mathrm{g} \text { BID (Pearl } \\
\text { Therapeutics) }\end{array}$ & Reisner et al $^{63}$ & $\begin{array}{l}\text { Increase in } \mathrm{FEV}, \mathrm{AUC}_{0-12} \text { on day } 7 \text { with combination compared } \\
\text { to monotherapy with either of the components, tiotropium, } \\
\text { and placebo }(P<0.000 \mathrm{I}) \text {. }\end{array}$ \\
\hline $\begin{array}{l}\text { Glycopyrrolate: } 36 \text { and } 72 \mu \mathrm{g} \text { BID; } \\
\text { formoterol: } 9.6 \mu \mathrm{g} \text { BID (Pearl }\end{array}$ & Reisner et al $^{64}$ & $\begin{array}{l}\text { Higher morning pretrough and peak IC with combination } \\
\text { vs placebo }(P<0.0005 \text { and } P<0.005 \text {, respectively }) \text { or }\end{array}$ \\
\hline Therapeutics) & & tiotropium monotherapy ( $P<0.05$ for all comparisons). \\
\hline $\begin{array}{l}\text { Glycopyrronium: } 50 \mu \mathrm{g} \text { QD; } \\
\text { indacaterol: } 300 \mu \mathrm{g} \text { QD (Novartis) }\end{array}$ & van Noord et al ${ }^{65}$ & $\begin{array}{l}\text { Improved trough } \mathrm{FEV} \text {, with combination: } 0.226 \mathrm{~L} \text { difference } \\
\text { in trough } \mathrm{FEV}_{\text {, }} \text { vs placebo }(P<0.00 \mathrm{I}) \text {. }\end{array}$ \\
\hline & & $\begin{array}{l}\text { Greater peak FEV, with combination (I.709 L) vs } 300 \mu g \\
\text { indacaterol }(\mathrm{I} .579 \mathrm{~L}) \text { and } 600 \mu \mathrm{g} \text { indacaterol }(\mathrm{I} .573 \mathrm{~L}) \text {; } \\
P<0.000 \text { I for both comparisons. }\end{array}$ \\
\hline $\begin{array}{l}\text { Glycopyrronium: I00 } \mu \mathrm{g} \text { QD; } \\
\text { indacaterol: } 600 \mu \mathrm{g} \text { QD (Novartis) }\end{array}$ & Van de Maele et $\mathrm{al}^{66}$ & $\begin{array}{l}\text { Increased trough } \mathrm{FEV} \text {, with combination }(\mathrm{I} .6 \mathrm{I} \mathrm{L}) \text { vs } \\
\text { indacaterol monotherapy } 300 \mu \mathrm{g}(\mathrm{I} .46 \mathrm{~L}) ; \mathrm{P}<0.05 \text {. }\end{array}$ \\
\hline $\begin{array}{l}\text { Glycopyrronium: } 50 \mu \mathrm{g} \text { QD; } \\
\text { indacaterol: I I0 } \mu \mathrm{g} \text { QD (Novartis) }\end{array}$ & Bateman et $\mathrm{al}^{67}$ & $\begin{array}{l}\text { Improved trough FEV, with combination vs placebo }(0.20 \mathrm{~L} \\
\text { mean difference), indacaterol }(0.07 \mathrm{~L}) \text {, glycopyrronium }(0.09 \mathrm{~L}) \text {, } \\
\text { and tiotropium }(0.08 \mathrm{~L}) \text { monotherapy; } P<0.00 \text { I. } \\
\text { Improved TDI score with combination vs placebo (mean } \\
\text { difference, I.09); } P<0.00 \text { I and tiotropium }(0.5 \text { I mean } \\
\text { difference); } P<0.05 \text {. } \\
\text { Improved SGRQ score with combination vs tiotropium } \\
\text { (-2.I3 mean difference); } P<0.05 \text {. } \\
\text { Reduced use of rescue medication with combination vs } \\
\text { monotherapies }(-0.30 \text { to }-0.54 \text { mean difference); } P<0.05 \text {. }\end{array}$ \\
\hline $\begin{array}{l}\text { Glycopyrronium: } 50 \text { g QD; } \\
\text { indacaterol: I } 10 \mu \mathrm{g} \text { QD (Novartis) }\end{array}$ & Vogelmeier et $\mathrm{al}^{68}$ & $\begin{array}{l}\text { Improvement in trough FEV, with combination vs salmeterol/ } \\
\text { fluticasone (mean difference } 0.103 \mathrm{~L} \text { ); } P<0.000 \mathrm{I} \text {. }\end{array}$ \\
\hline & & $\begin{array}{l}\text { Improvements in TDI score with combination vs salmeterol/ } \\
\text { fluticasone (mean difference } 0.76) ; P=0.003 \text {. } \\
\text { Lower use of rescue medication with combination vs } \\
\text { salmeterol/fluticasone ( }-0.39 \text { puffs/day); } P=0.019 \text {. }\end{array}$ \\
\hline $\begin{array}{l}\text { Glycopyrronium: } 50 \mu g \text { QD; } \\
\text { indacaterol: I I0 } \mu \mathrm{g} \text { QD (Novartis) }\end{array}$ & Dahl et $\mathrm{al}^{69}$ & $\begin{array}{l}\text { Combination increased } \mathrm{FEV} \text {, and FVC vs placebo over a } \\
52 \text {-week period; } P<0.001 \text {. }\end{array}$ \\
\hline $\begin{array}{l}\text { Tiotropium: } 5 \mu \mathrm{g} \text { QD; olodaterol: } \\
\text { 2, 5, and } 10 \mu \mathrm{g} \text { QD (Boehringer } \\
\text { Ingelheim) }\end{array}$ & Maltais et $\mathrm{al}^{70}$ & $\begin{array}{l}\text { Higher peak FEV, for all doses of combination investigated vs } \\
\text { tiotropium alone }(P \leq 0.05) \text {; higher trough FEV, response with } \\
\text { tiotropium + olodaterol } 5 / 10 \mu \mathrm{g} \text { vs tiotropium alone }(P=0.034) \text {. }\end{array}$ \\
\hline
\end{tabular}


Table 2 (Continued)

\begin{tabular}{|c|c|c|}
\hline Combination & Reference & Reported results \\
\hline Tiotropium: I.25, 2.5, and $5 \mu \mathrm{g}$ & Aalbers et $\mathrm{al}^{71}$ & Significant improvements in FEV, for all doses of combination vs \\
\hline QD; olodaterol: 5 and $10 \mu g$ QD & & olodaterol alone, with evidence of a dose-dependent \\
\hline (Boehringer Ingelheim) & & response. \\
\hline Umeclidinium (GSK573719): & Feldman et $\mathrm{al}^{72}$ & Adverse-event rate of $26 \%$, with no single adverse event \\
\hline \multirow[t]{4}{*}{$500 \mu \mathrm{g}$ QD; vilanterol: $25 \mu \mathrm{g}$ QD (GSK) } & & reported in >I patient. \\
\hline & & Combination similar to placebo in terms of cardiac parameters. \\
\hline & & Greater change from baseline in trough $\mathrm{FEV}_{1}$ and $\mathrm{FEV}$, from 0 to \\
\hline & & $6 \mathrm{~h}$ postdose with combination vs placebo. \\
\hline
\end{tabular}

Note: Adapted from Tashkin DP, Ferguson GT. Combination bronchodilator therapy in the management of chronic obstructive pulmonary disease. Respir Res. 20।3; 14:49.56 Abbreviations: LABA, long-acting $\beta_{2}$ agonist; LAMA, long-acting muscarinic antagonist; BID, twice a day; FEV , forced expiratory volume in I second; QD, once a day; AUC, area under the curve; TDI, Transition Dyspnea Index; IC, inspiratory capacity; SGRQ, St George's Respiratory Questionnaire; FVC, forced vital capacity.

dose inhaler or dry powder inhaler. ${ }^{14}$ There is a huge body of evidence suggesting the salvaging properties of formoterol in COPD in clinical practice, which is beyond the scope of this review. However, because of its acute and prolonged action, formoterol provides one of the best LABA options to be used in various combination therapies.

\section{The new LAMA: aclidinium bromide - pharmacology and clinical evidences Chemical composition}

Aclidinium is a quaternary ammonium derivative of a $(3 R)$ quinuclidinol ester containing two thiophene rings, and the chemical signature of aclidinium bromide is $(3 R)-3-y-1-(3-$ phenoxypropyl)-1-azoniabicyclo[2.2.2] octane bromide. ${ }^{15,16}$ The compound was developed by Almirall S.A. (Barcelona, Spain) and Forest Laboratories (New York, NY, USA). It is a muscarinic antagonist and has high binding affinity for the $\mathrm{M} 3$ receptor. Although it has a long duration of action and preliminary safety profile, quaternization of its tertiary amino function imparts a low oral bioavailability and low blood-brain barrier permeability, ${ }^{17}$ thereby reducing systemic exposure, especially via the inhaled route, and this has made it a drug of choice with low side effect profile compared to other muscarinic antagonists such as tiotropium. ${ }^{16}$

\section{Physiological effects}

Aclidinium has a high kinetic selectivity for M3 receptors in preference to other types of muscarinic receptors and is recommended as twice-a-day (BID) therapy in clinical practice. Some detailed analyses of the kinetics and receptor-binding activities have elucidated interesting results. ${ }^{17}$ Although the half-life of aclidinium at muscarinic receptors in guinea pig lung was found shorter when compared to tiotropium (29 hours vs 34 hours), aclidinium had a faster onset of action. ${ }^{18}$ In an in vitro study on isolated guinea pig trachea, Gavaldà et $a 1^{18}$ had shown that the onset of action of aclidinium ( $t_{1 / 2}=6.8 \pm 1.5$ minutes; $t_{\max }=35.9 \pm 8.2$ minutes) was faster than that of tiotropium $\left(t_{1 / 2}=13.6 \pm 2.7\right.$ minutes; $t_{\max }=61.2 \pm 10.6$ minutes), but similar to that of ipratropium $\left(t_{1 / 2}=5.1 \pm 1.5\right.$ minutes; $t_{\max }=24.1 \pm 3.5$ minutes) (Figure 1). In their study, they reported that when compared to tiotropium, aclidinium had significantly faster hydrolysis, with an extremely short half-life in human plasma (2 minutes). ${ }^{19}$ Another recent report has reconfirmed this previous finding and has shown that aclidinium had a shorter plasma half-life than glycopyrronium ( 2 minutes vs 12 hours).$^{20}$ This rapid plasma clearance of aclidinium suggests lower systemic and central nervous system side effects profile compared to other LAMAs. ${ }^{18}$ The systemic side effects of any drug remains a major concern in COPD because of its elderly population predominance with an increased propensity to comorbidities such as cardiovascular disease and altered metabolic profile.

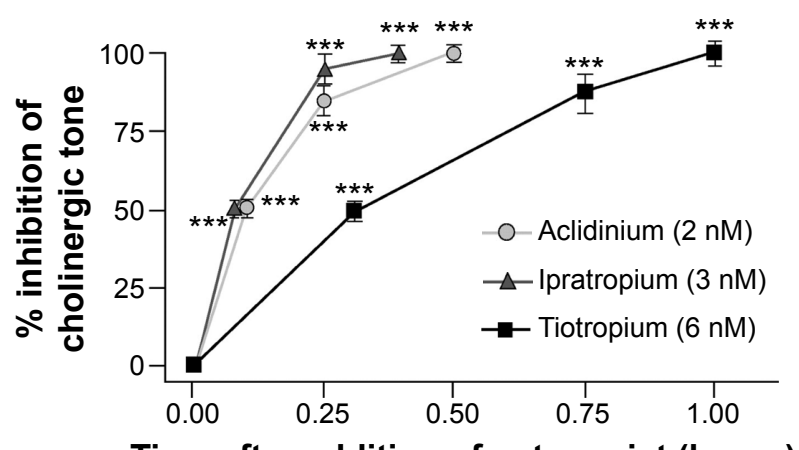

Time after addition of antagonist (hours)

Figure I Onset of action of aclidinium, ipratropium, and tiotropium in isolated guinea pig trachea.

Notes: Contraction was induced with $10 \mu \mathrm{M}$ carbachol and allowed to plateau before the addition of antagonists. Onset was defined as the time from antagonist addition to achieve inhibition of $50 \%\left(t_{1 / 2}\right)$ or $100 \%\left(t_{\max }\right)$ of the contraction. Data are reported as mean $\pm S E ; n=5-7$. $* * * p<0.00$ l compared with first observational time point. Copyright (C) 2009. Reproduced from The American Society for Pharmacology and Experimental Therapeutics. Gavaldà A, Miralpeix M, Ramos I, et al. Characterization of aclidinium bromide, a novel inhaled muscarinic antagonist, with long duration of action and a favorable pharmacological profile. J Pharmacol Exp Ther. 2009;33I(2):740-75I. ${ }^{18}$

Abbreviation: SE, standard error. 
Antimuscarinics are known to have significant cardiac side effects as a class effect. ${ }^{21}$ However, cardiac effects associated with aclidinium are much lower compared to other currently available antimuscarinics. In one study, tiotropium was shown to induce a significant increase in heart rate lasting for 6 hours, while aclidinium-induced increased heart rate lasted barely for 2.5 hours (Figure 2) ${ }^{18}$ Another preclinical cardiovascular safety study of the use of aclidinium further exemplified the lower side effects of aclidinium in comparison with tiotropium. ${ }^{22}$

\section{Efficacy and safety of aclidinium: evidence from studies}

Extensive clinical studies have been conducted to determine the efficacy of aclidinium in COPD. Aclidinium bromide has demonstrated significant bronchodilator potential in obstructive airway diseases. ${ }^{23-33}$ However, discussion on each of those studies is out of the scope of this paper. A Phase I trial showed that low to very high doses of aclidinium increased specific airway conductance $\left(\mathrm{sG}_{\mathrm{aw}}\right)$ of healthy adult individuals in a dose-dependent manner (Figure 3) ${ }^{26}$ Apart from its direct action on bronchoconstriction, aclidinium has been shown to contribute to a number of other favorable outcomes in obstructive airway diseases. Aclidinium has been found to reduce carbachol- and tobacco smoke-induced overexpression of MUC5AC, ${ }^{34}$ resulting in minimized secretion of mucin from goblet cells in COPD patients. ${ }^{35,36}$ Some of the major causes of exacerbation in COPD patients are exposure to airborne allergens and other environmental insults. These aeroallergens trigger an inflammatory response, which cannot be relieved by bronchodilators. Aclidinium, however, seems to be a better option than the other conventional bronchodilators because of its possible additional anti-inflammatory action. In a preclinical study, aclidinium has been shown to reduce Aspergillus fumigatus-induced eosinophil trafficking in bronchoalveolar lavage of mice in addition to complete abrogation of methacholine-induced increased airway resistance. ${ }^{37}$ This demonstrates significant additional clinical advantage of aclidinium in COPD as Aspergillus is a very ubiquitous saprophytic fungus.

A couple of Phase II and Phase III clinical trials investigated the safety aspects of the administration of aclidinium bromide in COPD patients. The ACCORD I (AClidinium in Chronic Obstructive Respiratory Disease I) study recruited 561 patients in that Phase III trial and stated that administration of 200 and $400 \mu \mathrm{g}$ aclidinium (BID) significantly improved bronchodilation, health status, and symptoms in moderate-to-severe COPD patients and that both the doses were well tolerated without untoward adverse effects for 12 weeks. ${ }^{38}$ Two more studies by Fuhr et $\mathrm{al}^{29}$ (Phase IIb trial) and Jones et $\mathrm{al}^{30}$ (Phase III trial - the ATTAIN (Aclidinium To Treat Airway obstruction In COPD patieNts) study) also strongly advocated the administration of 200 and $400 \mu \mathrm{g}$ aclidinium twice daily as safe doses in management of moderate-to-severe COPD. Later, Gelb et $\mathrm{al}^{31}$ and Beier et a ${ }^{32}$ also stated that either of the two doses (200 and $400 \mu \mathrm{g}$ ) of aclidinium twice daily was well tolerated by moderateto-severe COPD patients. However, the safety and efficacy

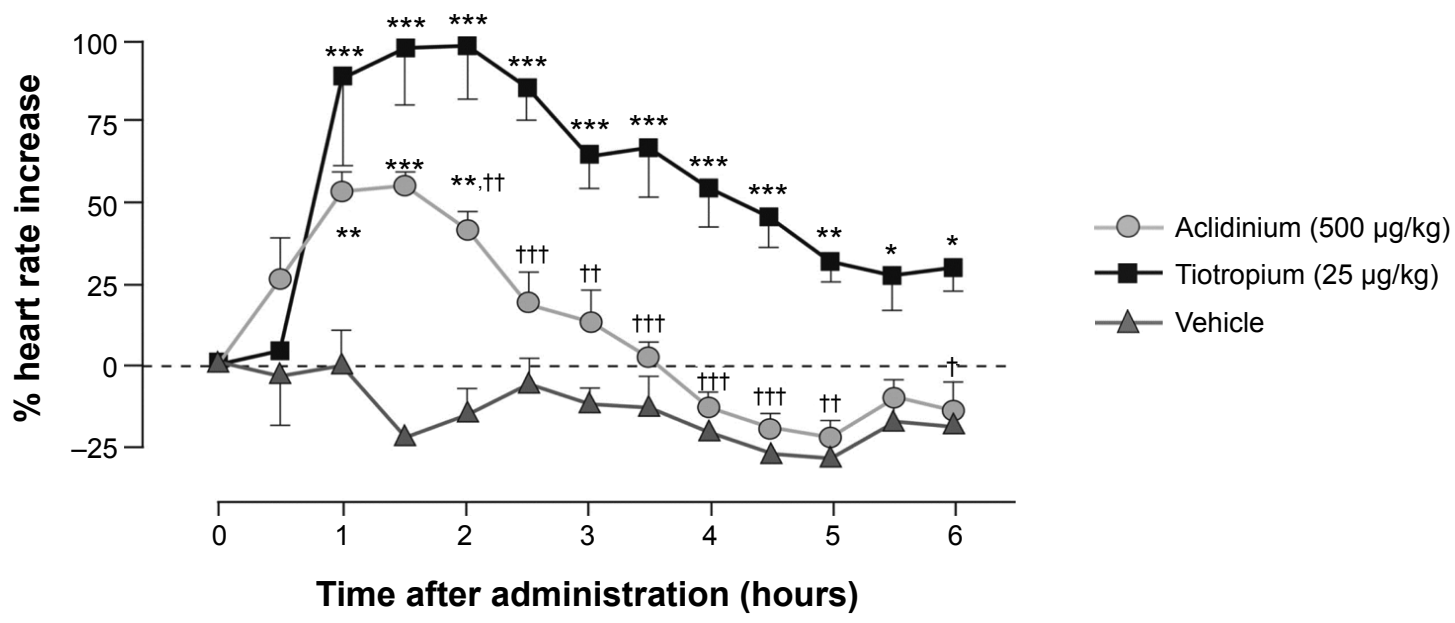

Figure 2 Effect of aclidinium and tiotropium on heart rate in conscious beagle dogs.

Notes: Animals were anesthetized in order to deliver the nebulized compounds or vehicle and were allowed to regain consciousness. The effect on heart rate of a dose 100 times higher than that used to achieve submaximal bronchodilation was assessed continuously up to 6 hours and expressed as a percentage change from baseline heart rate. Data are reported as mean $\pm \mathrm{SE} ; \mathrm{n}=4$ for aclidinium and tiotropium; $\mathrm{n}=3$ for vehicle. $* P<0.05, * * P<0.0$ I, $* * * P<0.00$ I compared with vehicle; ${ }^{\dagger} P<0.05$, ${ }^{\dagger} P<0.0$ I, $t+t P<0.001$ compared with tiotropium. Copyright @ 2009. Reproduced from The American Society for Pharmacology and Experimental Therapeutics. Gavaldà A, Miralpeix M, Ramos I, et al. Characterization of aclidinium bromide, a novel inhaled muscarinic antagonist, with long duration of action and a favorable pharmacological profile. J Pharmacol Exp Ther. 2009;33I(2):740-75I. ${ }^{18}$

Abbreviation: SE, standard error. 


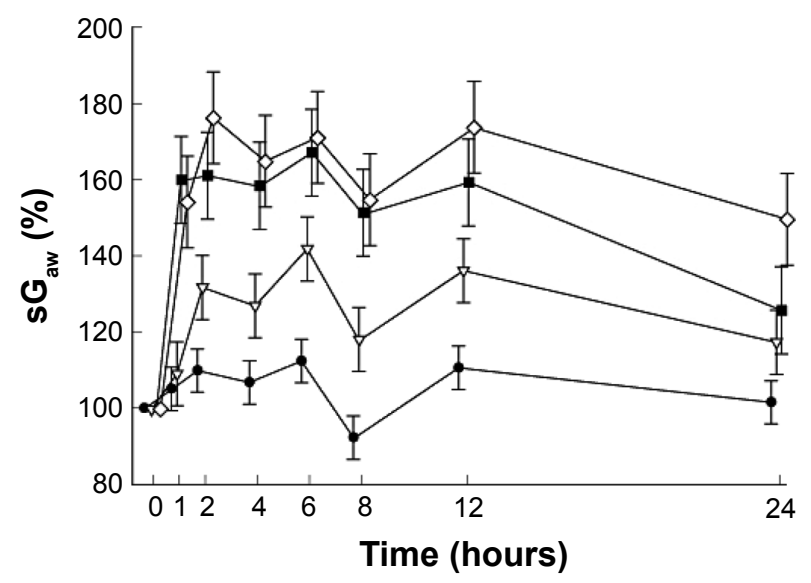

Figure 3 Mean $( \pm S E)$ changes in $s G_{a w}(\%)$ over 24 hours as a percentage of baseline value.

Notes: Placebo (- - ), $50 \mathrm{mg}$ aclidinium bromide $(-\nabla-), 300 \mathrm{mg}$ aclidinium bromide $(-$ ), $600 \mathrm{mg}$ aclidinium bromide ( $(-)$. (C) 2010 The Authors. Journal compilation (C) 2010 The British Pharmacological Society. Reproduced from Schelfhout VJ, Ferrer $\mathrm{P}$, Jansat JM, et al. Activity of aclidinium bromide, a new long-acting muscarinic antagonist: a phase I study. Br J Clin Pharmacol. 2010;69(5):458-464. ${ }^{26}$

Abbreviations: $\mathrm{sG}_{2 \mathrm{w}}$, specific airway conductance; $\mathrm{SE}$, standard error.

of aclidinium were significantly established before (2011) by Jones et $\mathrm{al}^{39}$ when the investigators reviewed pooled evidences from two Phase III clinical trials (AClidinium CLinical trial Assessing efficacy and safety In Moderate to severe COPD patients - the ACCLAIM study).

\section{Aclidinium bromide/formoterol fixed-dose combination therapy - evidences from clinical trials}

In a very recent study, Cazzola et $\mathrm{l}^{40}$ probed the therapeutic effects of aclidinium and formoterol combination on isolated human bronchial experiments. Interestingly, the combination model indicated a synergistic action at the low doses of aclidinium and formoterol in inducing smooth muscle relaxation in acetylcholine-induced bronchial contraction. The combination therapy induced more additive response compared with the expected additive response of the individual drug (in segment bronchi: $+18.4 \% \pm 2.7 \%$; $P<0.05$ vs expected effect; in bronchioles: $+19.7 \% \pm 0.9 \%$; $P<0.05$ vs expected effect). This is one of the very few published preclinical studies on aclidinium/formoterol combinations that clearly highlights the bronchodilation potential of the combination formulation at different doses.

Almirall S.A. and Forest Laboratories have developed a aclidinium bromide/formoterol fumarate FDC. These two companies have been conducting a series of Phase II and Phase III clinical trials to establish the clinical efficacy of the combination. These clinical trials included parallel arms including monotherapy by either of the two drugs (aclidinium and formoterol) at various doses and placebo to compare the efficacy, tolerance, and safety of the combination drug. ${ }^{41}$ Although many of those trials have been completed, results are yet to be published. Table 3 elucidates the list of the trials that looked into different aspects of this combination drug in the management of COPD.

Apart from the aforementioned clinical trials, there are some studies that merit discussion, as some results are available in the form of published abstracts. Sliwinski et al ${ }^{42}$ reported a dose-response clinical trial that was aimed to assess the efficacy, safety, and pharmacokinetics of three different doses of formoterol $(6,12$, and $18 \mu \mathrm{g})$ combined with aclidinium bromide $200 \mu \mathrm{g}$ and compared against aclidinium bromide $200 \mu \mathrm{g}$ monotherapy and formoterol $12 \mu \mathrm{g}$ monotherapy. ${ }^{42}$ This was a large study in which treatment was administered daily for 4 weeks to 566 stable moderate-to-severe COPD patients. The investigators reported that aclidinium combined with formoterol exhibited greater improvements in pulmonary parameters than did either drug alone or placebo, and all combinations were significantly superior to placebo $(P<0.001)$ and to both the monotherapies $(P<0.001) .{ }^{42}$ Another Phase IIa clinical trial by Magnussen et $\mathrm{al}^{43}$ was designed to investigate the pharmacokinetics, safety, tolerability, and lung function efficacy of aclidinium bromide and formoterol combination delivered through different inhalers. ${ }^{43}$ In that randomized, single-blinded, crossover study, 24 moderate-to-severe COPD patients obtained either an FDC of aclidinium bromide $(200 \mu \mathrm{g})$ and formoterol $(12 \mu \mathrm{g})$ once daily through Genuair ${ }^{\circledR}$ (Almirall S.A.), or formoterol $(12 \mu \mathrm{g})$ twice daily through Aerolizer ${ }^{\circledR}$ or, once daily through two different inhalers (Aerolizer ${ }^{\circledR}$ and Genuair $^{\circledR}$, Almirall S.A.). ${ }^{43}$ Each of the 4-day treatment periods was separated by a 7-day washout period, and all four treatments were found to be safe and well tolerated and improve the lung function.

The efficacy and long-term safety of aclidinium bromide/ formoterol fumarate combination therapy in the management of COPD has been advocated in two recently published largescale clinical trials - the AUGMENT COPD study and the ACLIFORM-COPD (ACLIdinium FORMoterol-COPD) study. Aclidinium/formoterol fUmarate combination for investiGative use in the treatMENT of moderate-to-severe COPD (AUGMENT COPD) study (trial registration id: NCT01437397) was a 24-week double-blind study in which 1,692 patients with stable COPD were equally randomized to twice-daily treatment with an FDC of aclidinium $400 \mu \mathrm{g} /$ 

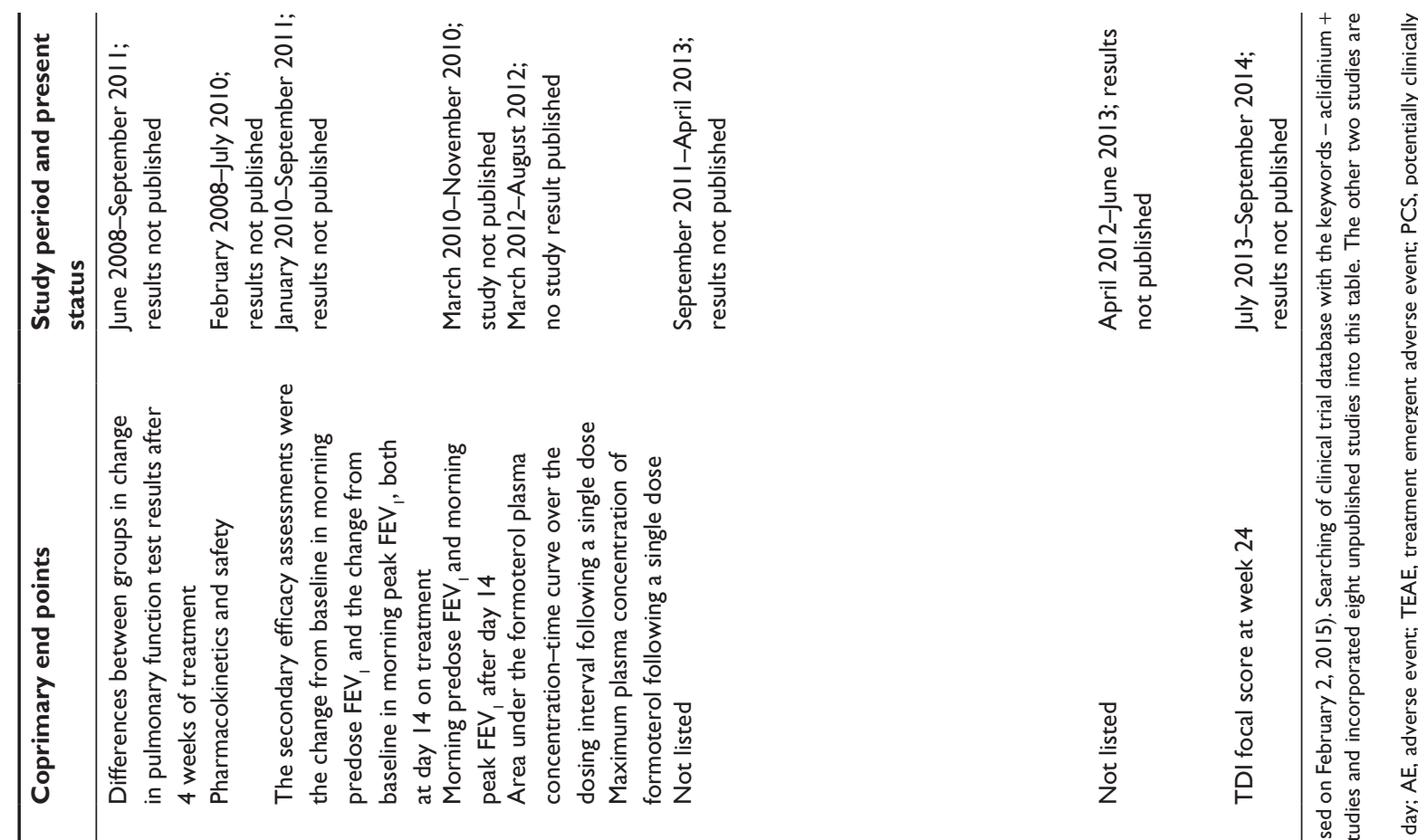

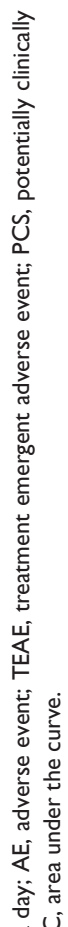
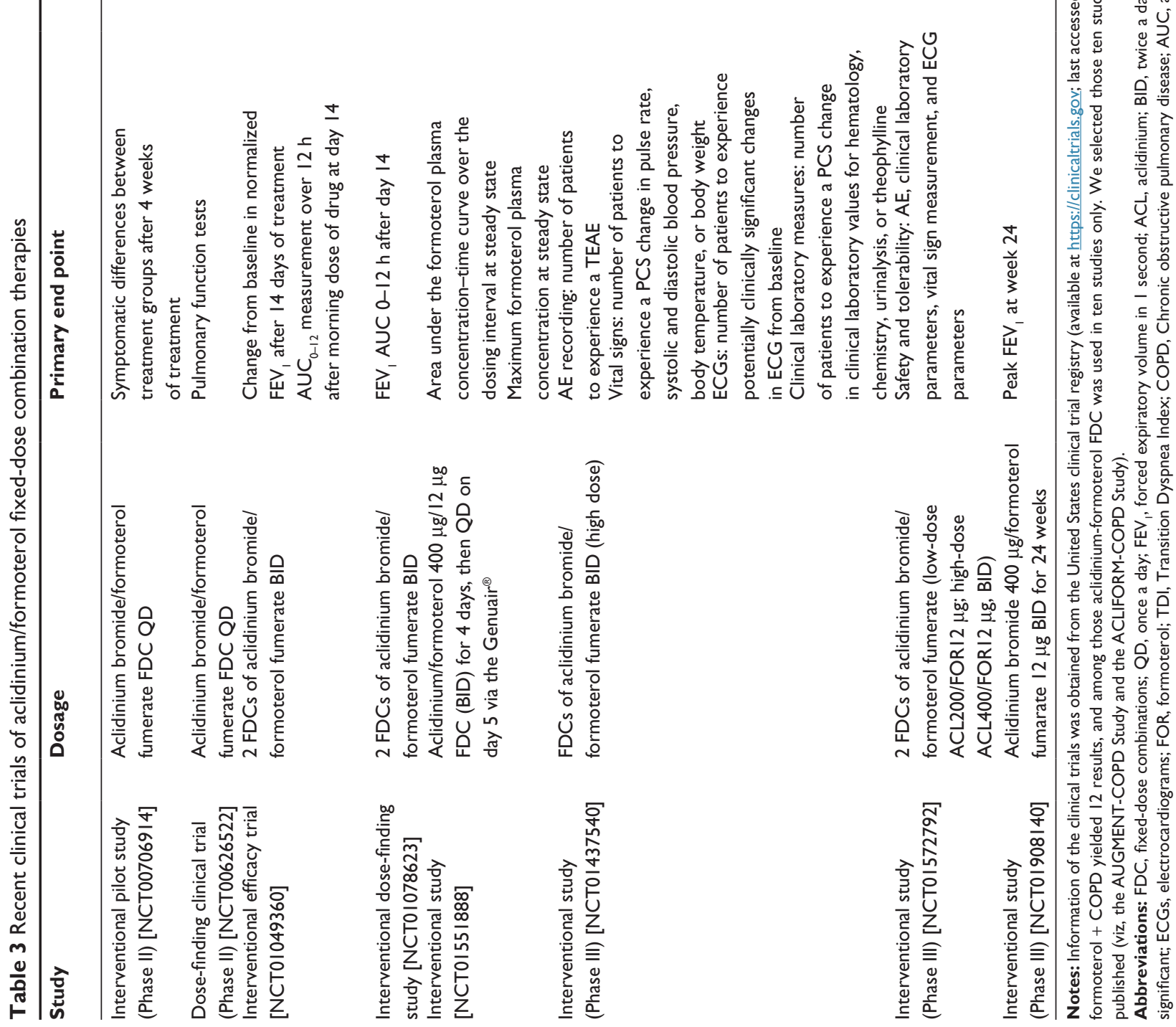
formoterol $12 \mu \mathrm{g}$ (ACL400/FOR12 FDC), FDC aclidinium $400 \mu \mathrm{g} /$ formoterol $6 \mu \mathrm{g}$ (ACL400/FOR6 FDC), aclidinium $400 \mu \mathrm{g}$, formoterol $12 \mu \mathrm{g}$, or placebo. All the drugs were administered by a multidose dry powder inhaler (Genuair ${ }^{\circledR} /$ Pressair $^{\circledR}$, Almirall S.A.). ${ }^{44}$ The primary end points of this study were change from baseline to week 24 in 1-hour morning postdose $\mathrm{FEV}_{1}$ (FDCs vs aclidinium) and change from baseline to week 24 in morning predose (trough) $\mathrm{FEV}_{1}$ (FDCs vs formoterol), while the secondary end points were change from baseline in SGRQ total score and improvement in Transition Dyspnea Index (TDI) focal score at week 24. The study also assessed the safety and tolerability of the FDCs. The study was completed in 2012. In accordance to the results, COPD patients treated with ACL400/FOR12 FDC or ACL400/FOR6 FDC had exhibited greater 1-hour postdose improvement in $\mathrm{FEV}_{1}$ from baseline than did those patients who received aclidinium alone $(108$ and $87 \mathrm{~mL}$, respectively; $P<0.001)$. Similarly, patients who received ACL400/FOR12 FDC had a significant $(P=0.01) 45 \mathrm{~mL}$ improvement in trough $\mathrm{FEV}_{1}$ than did those who received formoterol $12 \mu \mathrm{g}$ alone, although ACL400/FOR6 FDC showed only an insignificant $26 \mathrm{~mL}$ change over formoterol alone. Both the ACL/FOR FDCs induced rapid bronchodilation with significant improvement in $\mathrm{FEV}_{1}$ within 5 minutes of the morning dose on day 1 than aclidinium alone or formoterol alone or placebo (Figure $4 \mathrm{~A}$ ). $\mathrm{FEV}_{1}$ at 3 -hours postdose at week 24 also showed results similar to what was observed on day 1 (Figure 4B). Both SGRQ total and TDI focal scores also showed significant improvement at the end of the study in the ACL400/FOR12 FDC group over placebo with differences over placebo exceeding the minimal clinically important difference of $\geq 4$ points and $\geq 1$ unit, respectively. The investigators concluded that treatment with twice-daily aclidinium $400 \mu \mathrm{g} /$ formoterol $12 \mu \mathrm{g}$ FDC could help provide rapid and sustained bronchodilation over monotherapy with either drugs, which also helped in improving dyspnea and the health status of the COPD patients. ${ }^{44}$ This was a conventional clinical trial and there were hardly any limitations in the study design.

Another study published interesting outcomes of aclidinium bromide/formoterol FDC therapy, which had end points similar to those of the aforementioned study.

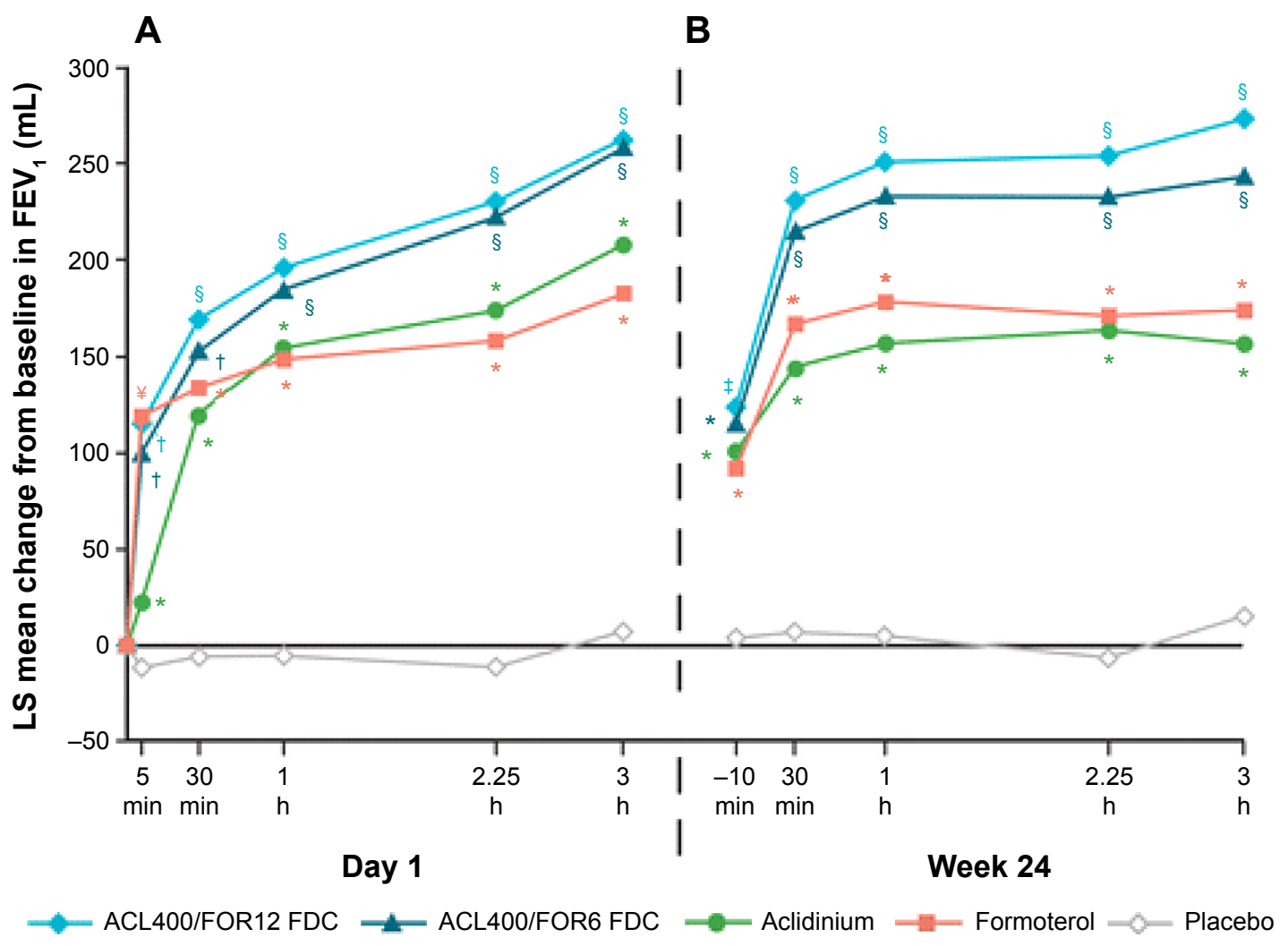

Figure 4 Mean changes from baseline in FEV , 0-3 hours (A) on day I and (B) at week 24.

Notes: Analyses were based on a mixed model for repeated measures. ${ }^{*} P<0.05$ vs placebo; ${ }^{\dagger}<0.05$ vs aclidinium and placebo; ${ }^{\S}<<0.05$ vs aclidinium, formoterol, and placebo; ${ }^{\sharp} P<0.05$ vs aclidinium/formoterol FDC $400 / 6 \mu \mathrm{g}$ and placebo. No significant differences between the two FDCs at any time point. Reproduced from D'Urzo AD, Rennard SI, Kerwin EM, Mergel V, Leselbaum AR, Caracta CF; AUGMENT COPD Study Investigators. Efficacy and safety of fixed-dose combinations of aclidinium bromide/ formoterol fumarate: the 24-week, randomized, placebo-controlled AUGMENT COPD study. Respir Res. 20I4; I5(I): I23. ${ }^{44}$

Abbreviations: ACL, aclidinium; FOR, formoterol; LS, least squares; FEV , forced expiratory volume in I second; FDCs, fixed-dose combinations; ACL400/FORI2 FDC, FDC of aclidinium $400 \mu \mathrm{g}$ and formoterol $12 \mu \mathrm{g}$; ACL400/FOR6 FDC, FDC of aclidinium $400 \mu \mathrm{g}$ and formoterol $6 \mu \mathrm{g}$. 
The ACLIFORM-COPD study (NCT01462942) was a double-blind, randomized, parallel group, active- and placebocontrolled, multicenter study conducted at 193 centers in 22 countries. ${ }^{45}$ In this study, patients with stable, moderate-tosevere COPD were randomized with a double-blind treatment of twice-daily aclidinium/formoterol FDC 400/12 $\mu \mathrm{g}$ or FDC $400 / 6 \mu \mathrm{g}$, aclidinium $400 \mu \mathrm{g}$ and formoterol $12 \mu \mathrm{g}$ or placebo. All medications were administered via a breath-actuated, multiple-dose dry powder inhaler (Genuair ${ }^{\circledR} /$ Pressair $^{\circledR}$, Almirall S.A.). The investigators reported that when compared to aclidinium monotherapy, both the FDCs of aclidinium and formoterol led to significant improvements in 1-hour postdose $\mathrm{FEV}_{1}$ from baseline $(125 \mathrm{~mL}$ in ACL400/FOR12 [95\% CI: $90-160, P<0.001]$ and $69 \mathrm{~mL}$ in ACL400/FOR6 [95\% CI: $34-105, P<0.001])$. The results were very close to what the other group had shown (108 and $87 \mathrm{~mL}$, respectively). ${ }^{44}$ Changes in trough $\mathrm{FEV}_{1}$ in the FDC groups in contrast to the formoterol alone were found to be $85 \mathrm{~mL}$ (95\% CI: 51-119; $P<0.001)$ and $53 \mathrm{~mL}$ (95\% CI: 19-87; $P<0.01)$, respectively, which were higher than those observed in the other study. In addition to that, ACL400/FOR12 and ACL400/FOR6 provided significant improvements in TDI focal score compared with placebo (1.29 units [95\% CI: $0.73,1.86 ; P<0.001]$ and 1.16 units [95\% CI: 0.59, 1.73; $P<0.001]$, respectively (Figure 5)). This study also concluded that both the FDCs of aclidinium and formoterol significantly improved bronchodilation when compared with monotherapy, without any additional risk. ${ }^{45}$

\section{Discussion}

These clinical trials have strongly advocated the potential therapeutic advantages of the use of aclidinium/formoterol
FDC therapies, as they are superior to either drugs alone and safe over long periods of time. What could be next? The latest update by $\mathrm{GOLD}^{8}$ also does not settle all the questions. A new combination therapy always raises the concern of efficacy and safety. ${ }^{46}$ The efficacy of aclidinium + formoterol in reducing exacerbations would need a 6- or 12-monthlong trial. Patient-reported outcomes also would require large multicentric trials possibly involving all phenotypes of COPD. It is definitely a great challenge to formulate the right LABA/LAMA combination that could be delivered along with a corticosteroid, and here the evidence of safety and efficacy of aclidinium/formoterol combination raises a potential option to be delivered as a triple-drug therapy (either separately or as a mixture with ICS) in the management of COPD globally, although such combination therapies need to be tested in patients with frequent exacerbations. Although it may be assumed that such combination therapies would help improve the quality of life of the patients and increase the patient adherence, the availability of such drugs is still very limited. ${ }^{47}$

\section{Conclusion}

The FDC of aclidinium bromide and formoterol fumarate holds the promise of round-the-clock control of symptoms of stable moderate-to-severe COPD with significant lung function improvement. However, the effect of this combination in reducing risk of exacerbations in relevant phenotypes of COPD and in improving patient-reported outcome measures and health-related quality-of-life measures in the long term remains to be established. It is worth waiting for further investigations of this FDC and also potentially its

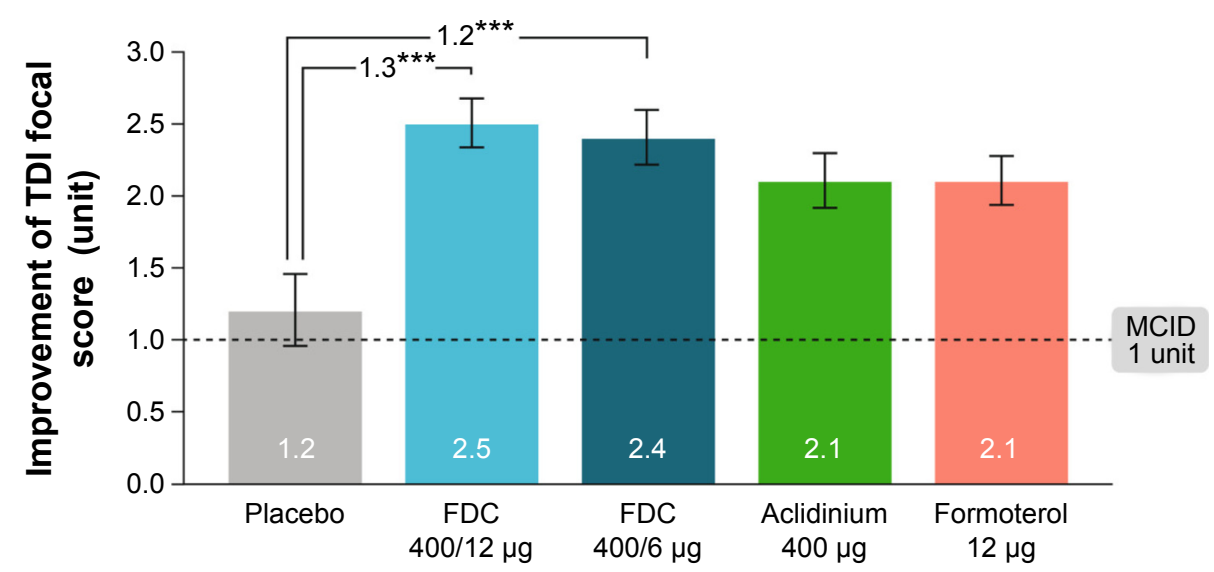

Figure 5 Improvement in TDI focal score at 24 weeks (ITT population).

Notes: Data are presented as least squares means (SE). $* * * P<0.001$ vs placebo. Reproduced from Singh D, Jones PW, Bateman ED, et al. Efficacy and safety of aclidinium bromide/formoterol fumarate fixed-dose combinations compared with individual components and placebo in patients with COPD (ACLIFORM-COPD): a multicentre, randomised study. BMC Pulm Med. 2014;14:I78. http://creativecommons.org/licenses/by/4.0/. ${ }^{45}$

Abbreviations: FDC, aclidinium/formoterol fixed-dose combination; ITT, intent-to-treat; MCID, minimum clinically important difference; SE, standard error; TDI, Transition Dyspnea Index. 
incorporation into triple-drug therapy as a free combination or single-inhaler FDC.

\section{Disclosure}

The authors report no conflicts of interest in this work.

\section{References}

1. Casaburi R, Mahler DA, Jones PW, et al. A long-term evaluation of once-daily inhaled tiotropium in chronic obstructive pulmonary disease. Eur Respir J. 2002;19(2):217-224.

2. Rabe KF, Hurd S, Anzueto A, et al; Global Initiative for Chronic Obstructive Lung Disease. Global strategy for the diagnosis, management, and prevention of chronic obstructive pulmonary disease: GOLD executive summary. Am J Respir Crit Care Med. 2007;176(6):532-555.

3. Chapman KR, Mannino DM, Soriano JB, et al. Epidemiology and costs of chronic obstructive pulmonary disease. Eur Respir J. 2006; 27(1):188-207.

4. Mathers CD, Loncar D. Projections of global mortality and burden of disease from 2002 to 2030. PLoS Med. 2006;3(11):e442.

5. Mannino DM, Buist AS. Global burden of COPD: risk factors, prevalence, and future trends. Lancet. 2007;370(9589):765-773.

6. Vestbo J, Hurd SS, Agustí AG, et al. Global strategy for the diagnosis, management, and prevention of chronic obstructive pulmonary disease: GOLD executive summary. Am J Respir Crit Care Med. 2013;187: 347-365.

7. Cazzola M, Page CP, Calzetta L, et al. Pharmacology and therapeutics of bronchodilators. Pharmacol Rev. 2012;64:450-504.

8. Global Initiative for Chronic Obstructive Lung Disease (GOLD). Global strategy for the diagnosis, management and prevention of COPD. 2015. Available from: http://www.goldcopd.org/. Accessed February 4, 2015.

9. Cazzola M, Brusasco V, Centanni S, et al. Project PriMo: sharing principles and practices of bronchodilator therapy monitoring in COPD: a consensus initiative for optimizing therapeutic appropriateness among Italian specialists. Pulm Pharmacol Ther. 2013;26:218-228.

10. van der Molen T, Cazzola M. Beyond lung function in COPD management: effectiveness of LABA/LAMA combination therapy on patientcentred outcomes. Prim Care Respir J. 2012;21:101-108.

11. Palmqvist M, Ibsen T, Mellen A, Lotvall J. Comparison of the relative efficacy of formoterol and salmeterol in asthmatic patients. Am J Respir Crit Care Med. 1999;160:244-249.

12. Aalbers R, Ayres J, Backer V, et al. Formoterol in patients with chronic obstructive pulmonary disease: a randomized, controlled, 3-month trial. Eur Respir J. 2002;19(5):936-943.

13. Gross NJ, Nelson HS, Lapidus RJ, et al; Formoterol Study Group. Efficacy and safety of formoterol fumarate delivered by nebulization to COPD patients. Respir Med. 2008;102(2):189-197.

14. Tashkin DP, Fabbri LM. Long-acting beta-agonists in the management of chronic obstructive pulmonary disease: current and future agents. Respir Res. 2010;11:149.

15. Norman P. Long-acting muscarinic M3 receptor antagonists. Expert Opin Ther Pat. 2006;16:1315-1320.

16. Prat M, Fernandez D, Buil MA, et al. Discovery of novel quaternary ammonium derivatives of (3R)-quinuclidinol esters as potent and long-acting muscarinic antagonists with potential for minimal systemic exposure after inhaled administration: identification of (3R)-3-\{[hydroxy(di-2-thienyl)acetyl]oxy\}-1-(3-phenoxypropyl)-1azoniabicyclo[2.2.2] octane bromide (aclidinium bromide). J Med Chem. 2009;52(16):5076-5092.

17. Moulton BC, Fryer AD. Muscarinic receptor antagonists, from folklore to pharmacology; finding drugs that actually work in asthma and COPD. Br J Pharmacol. 2011;163:44-52.

18. Gavaldà A, Miralpeix M, Ramos I, et al. Characterization of aclidinium bromide, a novel inhaled muscarinic antagonist, with long duration of action and a favorable pharmacological profile. J Pharmacol Exp Ther. 2009;331(2):740-751.
19. Gavaldà A, Miralpeix M, Ramos I, et al. Aclidinium bromide, a novel muscarinic receptor combining long residence at $\mathrm{M} 3$ receptors and rapid plasma clearance. Eur Respir J. 2007;30(Suppl 51):209S-210S.

20. Gavaldà A, Ramos I, Carcasona $\mathrm{C}$, et al. The in vitro and in vivo profile of aclidinium bromide in comparison with glycopyrronium bromide. Pulm Pharmacol Ther. 2014;28:114-121.

21. Beasley R, Singh S, Loke YK, Enright P, Furberg CD. Call for worldwide withdrawal of tiotropium Respimat mist inhaler. $B M J$. 2012;345:e7390.

22. Gras J, Gavaldà A, Llenas J. The preclinical cardiovascular safety profile of aclidinium bromide, a novel long-acting anticholinergic drug. Am J Respir Crit Care Med. 2008;177:A654.

23. Cazzola M, Matera MG. Novel long-acting bronchodilators for COPD and asthma. Br J Pharmacol. 2008;155:291-299.

24. Chanez P, Burge PS, Dahl R, et al. Aclidinium bromide provides longacting bronchodilation in patients with COPD. Pulm Pharmacol Ther. 2010;23:15-21.

25. Joos GF, Schelfhout VJ, Pauwels RA, et al. Bronchodilatory effects of aclidinium bromide, a long-acting muscarinic antagonist, in COPD patients. Respir Med. 2010;104:865-872.

26. Schelfhout VJ, Ferrer P, Jansat JM, et al. Activity of aclidinium bromide, a new long-acting muscarinic antagonist: a phase I study. $B r J$ Clin Pharmacol. 2010;69(5):458-464.

27. Maltais F, Celli B, Casaburi R, et al. Aclidinium bromide improves exercise endurance and lung hyperinflation in patients with moderate to severe COPD. Respir Med. 2011;105:580-587.

28. Singh D, Magnussen H, Kirsten A, et al. A randomized, placeboand active-controlled dose-finding study of aclidinium bromide administered twice a day in COPD patients. Pulm Pharmacol Ther. 2012;25:248-253

29. Fuhr R, Magnussen H, Sarem K, et al. Efficacy of aclidinium bromide $400 \mu \mathrm{g}$ twice daily compared with placebo and tiotropium in patients with moderate to severe COPD. Chest. 2012;141(3):745-752.

30. Jones PW, Singh D, Bateman ED, et al. Efficacy and safety of twicedaily aclidinium bromide in COPD patients: the ATTAIN study. Eur Respir J. 2012;40:830-836.

31. Gelb AF, Tashkin DP, Make BJ, et al. Long-term safety and efficacy of twice-daily aclidinium bromide in patients with COPD. Respir Med. 2013;107:1957-1965.

32. Beier J, Kirsten AM, Mróz R, et al. Efficacy and safety of aclidinium bromide compared with placebo and tiotropium in patients with moderateto-severe chronic obstructive pulmonary disease: results from a 6-week, randomized, controlled phase IIIb study. COPD. 2013;10:511-522.

33. Rottenkolber M, Rottenkolber D, Fischer R, et al. Inhaled beta-2 agonists/muscarinic antagonists and acute myocardial infarction in COPD patients. Respir Med. 2014;108:1075-1090.

34. Cortijo J, Mata M, Milara J, et al. Aclidinium inhibits cholinergic and tobacco smoke-induced MUC5AC in human airways. Eur Respir J. 2011;37(2):244-254.

35. Caramori G, Casolari P, Di Gregorio C, et al. MUC5AC expression is increased in bronchial submucosal glands of stable COPD patients. Histopathology. 2009;55(3):321-331.

36. Innes AL, Woodruff PG, Ferrando RE, et al. Epithelial mucin stores are increased in the large airways of smokers with airflow obstruction. Chest. 2006;130(4):1102-1108.

37. Damera G, Jiang M,Zhao H, et al. Aclidinium bromide abrogates allergeninduced hyperresponsiveness and reduces eosinophilia in murine model of airway inflammation. Eur J Pharmacol. 2010;649(1-3):349-353.

38. Kerwin EM, D'Urzo AD, Gelb AF, Lakkis H, Garcia Gil E, Caracta CF; ACCORD I study investigators. Efficacy and safety of a 12-week treatment with twice-daily aclidinium bromide in COPD patients (ACCORD COPD I). COPD. 2012;9(2):90-101.

39. Jones PW, Rennard SI, Agusti A, et al. Efficacy and safety of oncedaily aclidinium in chronic obstructive pulmonary disease. Respir Res. 2011;12(1):55.

40. Cazzola M, Calzetta L, Page CP, et al. Pharmacological characterization of the interaction between aclidinium bromide and formoterol fumarate on human isolated bronchi. Eur J Pharmacol. 2014;745:135-143. 
41. Cazzola M, Rogliani P, Matera MG. Aclidinium bromide/formoterol fumerate fixed-dose combination for the treatment of chronic obstructive pulmonary disease. Expert Opin Pharmacother. 2013;14(6):775-781.

42. Sliwinski P, Perng D-W, Chuchalin A, Jones PW. Efficacy and safety of once-daily aclidinium bromide $200 \mu \mathrm{g}$ in combination with formoterol in patients with COPD. Thorax. 2010;65:A136.

43. Magnussen H, Watz H, Kretschmar G, et al. Pharmakokinetik, Sicherheit und Aktivitat von formoterol verabreicht uber den Genuair Inhalator ${ }^{\mathbb{B}}$ mit und ohne Aclidinium-Bromid. Pneumologie. 2011;65:V446. German.

44. D’Urzo AD, Rennard SI, Kerwin EM, Mergel V, Leselbaum AR, Caracta CF; AUGMENT COPD Study Investigators. Efficacy and safety of fixed-dose combinations of aclidinium bromide/formoterol fumarate: the 24-week, randomized, placebo-controlled AUGMENT COPD study. Respir Res. 2014;15(1):123

45. Singh D, Jones PW, Bateman ED, et al. Efficacy and safety of aclidinium bromide/formoterol fumarate fixed-dose combinations compared with individual components and placebo in patients with COPD (ACLIFORMCOPD): a multicentre, randomised study. BMC Pulm Med. 2014;14:178.

46. Cazzola M, Segreti A, Rogliani P. Comparative effectiveness of drugs for chronic obstructive pulmonary disease. Drugs Today. 2012;48(12): 785-794.

47. Salama RO, Young PM, Rogueda P, et al. Advances in drug delivery: is triple therapy the future for the treatment of chronic obstructive pulmonary disease? Expert Opin Pharmacother. 2011;12:1913-1932.

48. Moen MD. Indacaterol: in chronic obstructive pulmonary disease Drugs. 2010:70:2269-2280.

49. van Noord JA, Korducki L, Hamilton A, Koker P. Four weeks once daily treatment with BI $1744 \mathrm{CL}$, a novel long-acting $\beta 2$-agonist, is effective in COPD patients [abstract]. Am J Respir Crit Care Med. 2009;179:A6183.

50. Hanania NA, Feldman G, Zachgo W, et al. Dose-related efficacy of vilanterol trifenatate (VI) in COPD [abstract]. Eur Respir J. 2010; 36(Suppl 54):217s.

51. Vestbo J, Vogelmeier C, Creemers J, Falques M, Ribera A, Garcia Gil E. Onset of effect of aclidinium, a novel, long-acting muscarinic antagonist, in patients with COPD. COPD. 2010;7:331-336.

52. Verkindre C, Fukuchi Y, Flémale A, et al. Sustained 24-h efficacy of NVA237, a once-daily long-acting muscarinic antagonist, in COPD patients. Respir Med. 2010;104:1482-1489.

53. Kerwin EM, Hebert J, Pedinoff A, et al. NVA237 once daily provides rapid and sustained bronchodilation in COPD patients, with efficacy similar to tiotropium: the GLOW2 trial [abstract]. Am J Respir Crit Care Med. 2012;185:A2920.

54. Bateman E, Feldman G, Kilbride S, et al. Efficacy and safety of the long-acting muscarinic antagonist GSK233705 delivered once daily in patients with COPD. Clin Respir J. 2012;6:248-257.

55. Casaburi R, Briggs DD Jr, Donohue JF, Serby CW, Menjoge SS, Witek TJ Jr, for the US Tiotropium Study Group. The spirometric efficacy of once-daily dosing with tiotropium in stable COPD. A 13-week multicenter trial. Chest. 2000;118:1294-1302.

56. Tashkin DP, Ferguson GT. Combination bronchodilator therapy in the management of chronic obstructive pulmonary disease. Respir Res. 2013;14:49.

57. Beier J, van Noord J, Deans A, et al. Safety and efficacy of dual therapy with GSK233705 and salmeterol versus monotherapy with salmeterol, tiotropium, or placebo in a crossover pilot study in partially reversible COPD patients. Int J Chron Obstruct Pulmon Dis. 2012;7:153-164.

Drug Design, Development and Therapy

\section{Publish your work in this journal}

Drug Design, Development and Therapy is an international, peerreviewed open-access journal that spans the spectrum of drug design and development through to clinical applications. Clinical outcomes, patient safety, and programs for the development and effective, safe, and sustained use of medicines are a feature of the journal, which
58. Tashkin DP, Donohue JF, Mahler DA, et al. Effects of arformoterol twice daily, tiotropium once daily, and their combination in patients with COPD. Respir Med. 2009;103:516-524.

59. Hanania NA, Boota A, Kerwin E, Tomlinson L, Denis-Mize K. Efficacy and safety of nebulized formoterol as add-on therapy in COPD patients receiving maintenance tiotropium bromide: results from a 6-week, randomized, placebo-controlled, clinical trial. Drugs. 2009;69:1205-1216.

60. Tashkin DP, Pearle J, Iezzoni D, Varghese ST. Formoterol and tiotropium compared with tiotropium alone for treatment of COPD. COPD. 2009;6:17-25

61. Vogelmeier C, Kardos P, Harari S, Gans SJ, Stenglein S, Thirlwell J. Formoterol mono- and combination therapy with tiotropium in patients with COPD: a 6-month study. Respir Med. 2008;102:1511-1520.

62. van Noord JA, Aumann J-L, Janssens E, et al. Combining tiotropium and salmeterol in COPD: effects on airflow obstruction and symptoms. Respir Med. 2010;104:995-1004.

63. Reisner C, Fogarty C, Spangenthal S, et al. Novel combination of glycopyrrolate and formoterol MDI (GFF-MDI) provides superior bronchodilation compared to its components administered alone, tiotropium DPI, and formoterol DPI in a randomized, double-blind, placebo-controlled Phase 2b study in patients with COPD [abstract] Am J Respir Crit Care Med. 2011;183:A6453.

64. Reisner C, St Rose E, Strom S, et al. Fixed combination of glycopyrrolate and formoterol MDI (GFF-MDI) demonstrates superior inspiratory capacity (IC) compared to tiotropium DPI (Tio) following 7 days dosing, in a randomized, double-blind, placebo-controlled phase $2 \mathrm{~b}$ study in patients with COPD [abstract]. Eur Respir J. 2011;(38 Suppl 55): $150 \mathrm{~s}$.

65. van Noord JA, Buhl R, LaForce C, et al. QVA149 demonstrates superior bronchodilation compared with indacaterol or placebo in patients with chronic obstructive pulmonary disease. Thorax. 2010;65:1086-1091.

66. Van de Maele B, Fabbri LM, Martin C, Horton R, Dolker M, Overend T. Cardiovascular safety of QVA149, a combination of indacaterol and NVA237, in COPD patients. COPD. 2010;7:418-427.

67. Bateman ED, Ferguson GT, Barnes N, et al. Dual bronchodilation with QVA149 versus single bronchodilator therapy: the SHINE study. Eur Respir J. 2013;42:1484-1494.

68. Vogelmeier CF, Bateman ED, Pallante J, et al. Efficacy and safety of once-daily QVA149 compared with twice-daily salmeterol-fluticasone in patients with chronic obstructive pulmonary disease (ILLUMINATE): a randomised, double-blind, parallel group study. Lancet Respir Med. 2013;1:51-60.

69. Dahl R, Chapman K, Rudolf M, et al. QVA149 administered once daily provides significant improvements in lung function over 1 year in patients with COPD: the ENLIGHTEN study [abstract]. Eur Respir J. 2012;40(Suppl 56):P2896.

70. Maltais F, Beck E, Webster D, et al. Four weeks once daily treatment with tiotropium + olodaterol (BI 1744) fixed dose combination compared with tiotropium in COPD patients [abstract]. Eur Respir J. 2010; 36(Suppl 54):1014s.

71. Aalbers R, Maleki-Yazdi MR, Hamilton A, et al. Dose-finding study for tiotropium and olodaterol when administered in combination via the Respimat ${ }^{\circledR}$ inhaler in patients with COPD. Eur Respir J. 2012;40(Suppl 56): $525 \mathrm{~s}$.

72. Feldman G, Walker RR, Brooks J, Mehta R, Crater G. Safety and tolerability of the GSK573719/vilanterol combination in patients with COPD [abstract]. Am J Respir Crit Care Med. 2012;185:A2938.

\section{Dovepress}

has also been accepted for indexing on PubMed Central. The manuscript management system is completely online and includes a very quick and fair peer-review system, which is all easy to use. Visit http://www.dovepress.com/testimonials.php to read real quotes from published authors. 